\title{
Hypolipidemic activity of Dracocephalum kotschyi involves FOXO1 mediated modulation of PPARY expression in adipocytes
}

\author{
Shima Aslian and Razieh Yazdanparast ${ }^{*}$ (1)
}

\begin{abstract}
Background: Dracocephalum kotschyi, as a wild-growing flowering plant (from Lamiaceae family), is locally prescribed for its various health-promoting properties including hypolipidemic and hypoglycemic effects. To evaluate the scientific basis of the traditional use of Dracocephalum kotschyi extract (DKE), we aimed to disclose its mode of action with main focus on white adipose tissue of diabetic rats.

Methods: Streptozotocin-induced diabetic rats were exposed to different doses of DKE for 28 days followed by the determination of the sera biochemical factors. The oxidative stress status of the diabetic versus nondiabetic rats' adipose tissue under the influence of DKE were also evaluated in terms of malondialdehyde (MDA) and some of antioxidant enzymes (superoxide dismutase, SOD, and catalase). Furthermore, we exposed 3T3-L1 cells to DKE and then evaluated both the extent of cells differentiation to adipocytes and measured the expression levels of some of the key signaling elements involved in adipogenesis and lipogenesis with main focus on PPARY.

Results: Our results indicated that DKE administration attenuated the levels of TG (triglycerides), TC (total cholesterol), LDL and blood glucose by $54,40,54$ and $25 \%$, respectively and enhanced the levels of HDL, catalase and SOD by 45, 74 and 56\%, respectively. In addition to profound adipogenic and lipogenic effects on 3T3-L1 cells, DKE significantly enhanced p-AKT, p-FOXO1, PPARY and SREBP-1 expressions while that of p-JNK was quenched parallel to effect of pioglitazone, an antidiabetic agent, used in our investigation as the positive control drug.

Conclusions: Besides of confirming the hypolipidemic action of the plant, our results provided documents on at least one mode of action of DKE with profound effect on lipid metabolism in adipose tissue. Regarding our results, further investigation on DKE, as a new potential hypolipidemic alternative drug is warranted.
\end{abstract}

Keywords: Adipose, Diabetes, Dracocephalum kotschyi, Lipogenesis, PPARY, SREBP-1

\section{Background}

Adipose tissue abnormality is registered as one of the known diabetic complications linking diabetes to adipose tissue malfunction. It has recently being shown that insulin sensitizing action of a group of drugs known as thiazolidinediones could be restored following transplantation of wild-type adipose-tissue into diabetic mice [1]. Thiazolidinediones, as a group of antidiabetic agents, and similar to pioglitazone and rosiglitazone, act via

\footnotetext{
* Correspondence: ryazdan@ut.ac.ir

Institute of Biochemistry and Biophysics, University of Tehran, P.O. Box 13145-1384, Tehran, Iran
}

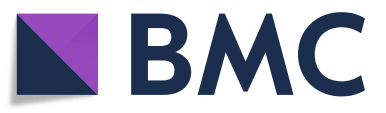

(c) The Author(s). 2018 Open Access This article is distributed under the terms of the Creative Commons Attribution 4.0 International License (http://creativecommons.org/licenses/by/4.0/), which permits unrestricted use, distribution, and

reproduction in any medium, provided you give appropriate credit to the original author(s) and the source, provide a link to the Creative Commons license, and indicate if changes were made. The Creative Commons Public Domain Dedication waiver (http://creativecommons.org/publicdomain/zero/1.0/) applies to the data made available in this article, unless otherwise stated.

activation of PPAR (peroxisome proliferator-activated receptor gamma) which associates with other lipogenic factors like SREBP-1 (sterol regulatory element-binding protein 1) to upregulate adipocyte differentiation (adipogenesis) and lipid metabolism (lipogenesis) [2]. In that line, it has been shown that adipose specific PPAR $\gamma$-knockout mice suffer from severe lipodystrophy and hyperlipidemia [3]. Thiazolidinediones, as PPAR $\gamma$ activators, induce adipose tissue remodeling where large adipocytes are replaced by small and more insulin sensitive cells [4]. 
On the other hand, partial protection against high fat diet-induced diabetes has been shown in FOXO1 (forkhead box O-1) haploinsufficient mice [5]. Based on the present literature data, FOXO1, as a suppressive transcription factor, attenuates PPAR $\gamma$ activity in adipocytes via binding and repressing the PPAR $\gamma$ promoter and/or via direct interaction with PPAR $\gamma$ protein [6]. Suppression of PPAR $\gamma$ activity is further intensified by JNK (c-Jun N-terminal kinase) activation via diabetes associated oxidative stress which facilitates nuclear localization and activation of FOXO1 in adipocytes [7].

Thus, modulation and mainly activation of PPARY activity among diabetic patients might constitute a therapeutic strategy for diabetic patients. Antioxidants, with suppressive effects on JNK activity, would lead to FOXO1 activity suppression via AKT (also known as protein kinase B) activation with subsequent augmentation of PPAR $\gamma$-associated lipogenesis and attenuation of blood glucose level. This mode of action might account for the hypoglycemic action of many herbal medicines rich in different groups of antioxidants.

In that line, we got interested to evaluate the probability of the aforementioned mechanism as the scientific basis for the traditional use of DKE as a hypoglycemic and hypolipidemic remedy in Iranian folk medicine with as yet unknown mode of action [8].

To document the lipogenic activity of DKE, in terms of PPAR $\gamma$ and FOXO1 activity modulation, we exposed a group of STZ (streptozotocin)-induced diabetic rats and 3T3-L1 (mouse embryonic fibroblast) cells to different doses of the extract for different time intervals as indicated in the text. Our data clearly confirmed the beneficial effects of DKE on PPAR $\gamma$ activation and FOXO1 deactivation in both the in vivo and the ex-vivo models and thus, scientifically approved the validity of the traditional use of DKE against diabetes and some of its complications.

\section{Materials and methods}

\section{Aim and design of the study}

For further investigations about hypolipidemic effects of Dracocephalum kotschyi, we prepared the plant's hydroalcoholic extract and evaluated its antidiabetic and antioxidant properties. Regarding DKE's definite hypolipidemic and moderate hypoglycemic effects, 3T3-L1 adipocytes were cultured in the presence of DKE and evaluated its adipogenic and/or lipogenic consequences. Furthermore, western blot analyses of total FOXO1, p-FOXO1, p-AKT, p-JNK, PPAR $\gamma$ and SREBP-1, as oxidative stress-related regulatory factors with established impact on lipid metabolism, were achieved to disclose the mode of DKE's antidiabetic action.

\section{Materials}

STZ, trichloroacetic acid and EDTA (ethylenediaminetetraacetic acid) were purchased from Sigma Chem. Co. (MO, USA); NADH (nicotinamide adenine dinucleotide), TBA (thiobarbituric acid) and NBT (nitroblue tetrazolium) were obtained from Merck Co. (Germany). Antibodies to p-AKT (Thr 308), p-FOXO1 (Ser 256) and FOXO1 were obtained from Cell Signaling Technology (MA, USA). Anti-PPAR $\gamma$ was purchased from Santa Cruz Biotechnology (Canada). Antibody to SREBP-1 was obtained from Abcam Co. (USA). Anti-tubulin and horseradish peroxidase conjugated secondary antibodies were supplied by Sigma Chem. Co. (Germany). Anti-JNK and anti-JNK1\&2[pTpY ${ }^{183 / 185}$ ] were obtained from Biosource (Nivelles, Belgium). All other chemicals were reagent grade and used without purification.

\section{Plant extract preparation}

Dracocephalum kotschyi aerial parts were collected from Alborz province of Iran and identified by Dr. Zare (Tehran University Herbarium, deposition code: 47418). Dried plant powder was incubated in ethanol water solution $(1: 1, v / v)$ for an overnight at room temperature followed by centrifugation at $1000 \times \mathrm{g}$ for $10 \mathrm{~min}$. This process was repeated for two more times. The combined extracts were then subjected to vacuum evaporation at $70{ }^{\circ} \mathrm{C}$ to a final volume (ml) equivalent to plant powder weight $(\mathrm{g})$. The concentrated extract was aliquoted and stored at $-20{ }^{\circ} \mathrm{C}$.

\section{Cell culture}

3T3-L1 preadipocytes were cultured in high glucose DMEM (Gibco. GI, USA) containing 10\% fetal bovine serum and $1 \%$ penicillin/streptomycin at $37{ }^{\circ} \mathrm{C}$ and $5 \% \mathrm{CO} 2$. Two days after confluency, the medium was replaced with DMI medium (high glucose DMEM containing $1 \mu \mathrm{M}$ dexamethasone, $0.5 \mathrm{mM}$ 3-isobutyl1-methylxanthine, and $1.5 \mu \mathrm{g} / \mathrm{ml}$ insulin). After $48 \mathrm{~h}$, the DMI medium was replaced by high glucose DMEM supplemented with $10 \mu \mathrm{g} / \mathrm{ml}$ insulin and $10 \%$ fetal bovine serum [9].

\section{Cell viability determination}

The MTT [3-(4,5-dimethylthiazol-2-yl)-2,5-diphenyltetrazolium bromide] die was used to evaluate the cell viability. The cells $\left(5 \times 10^{4} /\right.$ well $)$ were seeded in 96-well plates and incubated with $90 \mu \mathrm{l}$ complete DMEM. After $24 \mathrm{~h}$ of incubation, cells were treated with different concentrations $(0-20 \mu \mathrm{l} / \mathrm{ml})$ of DKE, for 24,48 and $72 \mathrm{~h}$ and the cell viability was determined using $10 \mu \mathrm{l}$ of MTT stock solution $(5 \mathrm{mg} / \mathrm{ml})$ for each well. Three hours after MTT addition, produced formazan crystals in each well were dissolved in $100 \mu \mathrm{l}$ DMSO and measured at $570 \mathrm{~nm}$. 
Determination of TG content in 3T3-L1 cells

After harvesting, $200 \mu \mathrm{l}$ PBS was added to the cells and suspensions were sonicated in ice bath for $3 \mathrm{~min}$ followed by centrifugation at $10000 \times \mathrm{g}$ for $10 \mathrm{~min}$ at $4{ }^{\circ} \mathrm{C}$ [10]. Protein concentration was determined using Lowry's method [11]. The TG content of each sample was determined using a relevant kit (Pars Azmun Co., Tehran, Iran) in accordance with manufacturer's instructions.

\section{Oil red $O$ staining and quantification}

Oil Red $\mathrm{O}$ staining was performed as described previously [12]. In order to quantify, plates left to dry completely and $1500 \mu \mathrm{l}$ of isopropanol was added to each well. Plates were incubated for $10 \mathrm{~min}$ at room temperature (wrapped with parafilm) and the concentration of dissolved Oil Red O was spectrophotometrically measured at $520 \mathrm{~nm}$.

\section{Animal treatments}

Seven days-acclimatized Wistar albino male rats, weighing between 220 and $250 \mathrm{~g}$, were treated with a single intraperitoneal injection of STZ ( $45 \mathrm{mg} / \mathrm{kg}$ body weight, dissolved in sodium citrate buffer, $0.1 \mathrm{M}, \mathrm{pH} 4.5$ ) and six rats (normal control group) were treated with the same volume of the vehicle. Three days after injection, the induction of diabetes was confirmed based on blood glucose level (above $250 \mathrm{mg} / \mathrm{dl}$ ) and rat groups $(n=6)$ were subjected to daily gavage treatments for 28 consecutive days. Normal and diabetic control groups received $1 \mathrm{ml}$ of distilled water. DKE-treated groups received $1 \mathrm{ml}$ of 1:4 and/or 1:2 extract:water dilutions. Positive control group received $1 \mathrm{ml}$ of pioglitazone (in distilled water).

\section{Biochemical analyses}

Immediately after collection, blood samples were placed on ice and allowed to clot, centrifuged at $3500 \times \mathrm{g}$ for $20 \mathrm{~min}\left(\right.$ at $4{ }^{\circ} \mathrm{C}$ ) and serum aliquots were stored at $70{ }^{\circ} \mathrm{C}$. Serum levels of glucose, TC, TG, LDL and HDL were measured using relevant kits (Pars Azmun Co., Tehran, Iran) in accordance with the manufacturer's instructions.

\section{Antioxidant enzyme assays and determination of lipid peroxidation}

To obtain tissue homogenates [13] epididymal adipose tissues were quickly excised from sacrificed rats, washed twice with cold PBS, frozen in liquid nitrogen, pulverized and homogenized in the solution $(1: 2 w / v)$ containing $154 \mathrm{mM} \mathrm{KCl}$ and $3 \mathrm{mM}$ EDTA, pH 7.4. Each homogenate was sonicated for $30 \mathrm{~s}$ and defatted by centrifugation, all steps were performed at $4{ }^{\circ} \mathrm{C}$. After protein determination of each sample, the activity of SOD (superoxide dismutase) was assayed based on inhibition of NBT reduction to formazan [14]. One unit of SOD activity was expressed as $50 \%$ inhibition of NBT reduction per minute per mg of protein. Catalase activity was determined by measuring the decomposition of $\mathrm{H} 2 \mathrm{O} 2$ per minute per mg of protein [15].

The level of MDA (malondialdehyde) was determined via spectrophotometric determination of the purple color of the reaction mixture. Briefly, $250 \mu \mathrm{l}$ of trichloroacetic acid solution $(10 \%, w / v)$ was added to $50 \mu \mathrm{l}$ of the defatted tissue homogenate, placed in a boiling water bath for $15 \mathrm{~min}$, cooled to room temperature and centrifuged at $1000 \times \mathrm{g}$ for $10 \mathrm{~min}$. Then $200 \mu \mathrm{l}$ of each supernatant was added to $100 \mu \mathrm{l}$ of TBA solution $(0.67 \%, w / v)$, placed in a boiling water bath for $15 \mathrm{~min}$ and the absorbance was measured at $532 \mathrm{~nm}$ at room temperature [16].

\section{Western blot analyses}

Frozen adipose tissues (100-120 mg) were separately pulverized in liquid nitrogen. To each sample $0.2 \mathrm{ml}$ RIPA lysis buffer was added followed by $30 \mathrm{~min}$ incubation on ice. Each homogenate was centrifuged at $14000 \times \mathrm{g}$ for $15 \mathrm{~min}$ at $4{ }^{\circ} \mathrm{C}$, defatted and the protein concentration was determined. Equal protein amounts were mixed with the loading buffer, electrophoresed and transferred to a polyvinylidene difluoride membrane. Membranes were blocked by $5 \%$ nonfat blocking solution for 1 hour and were then incubated overnight with the relevant primary antibody at $4{ }^{\circ} \mathrm{C}$ using BSA antibody dilution buffer followed by a 2 hour incubation at room temperature with the secondary antibody dilutions. The protein bands were detected by an enhanced chemiluminescence detection system (Amersham-Pharmacia, Piscataway, NJ) according to the manufacturer's instructions. The supernatants of the 3T3-L1 cells' extracts were also subjected to the same evaluation.

\section{Light microscopy and determination of adipocyte area}

Adipose tissue depots (100-150 mg) were covered with $10 \%$ formaldehyde in phosphate buffer saline, $\mathrm{pH} \mathrm{7.4}$, for $48 \mathrm{~h}$ at $4{ }^{\circ} \mathrm{C}$, dehydrated in ethanol, cleared in xylene and placed within paraffin. Three serial sections of each sample ( $3 \mu \mathrm{m}$ thickness) were stained with hematoxylin-eosin followed by light microscopic imaging at $\times 200$ magnification. In this study, the adipocyte area was determined using the free open access software ImageJ (http://rsbweb.nih.gov/ij/) and 300 cells were considered for each evaluation.

\section{Statistics}

Data are presented as the mean $\pm \mathrm{SD}$ (standard deviation) of at least three independent tests and different cell cultures were used for each independent experiment. Significant differences were assessed by independent student's t-test. 


\section{Results}

DKE's adipogenic and lipogenic effects in 3T3-L1 cells In most cases, the differentiation efficiency was very low using DMI medium. However, fully differentiated 3T3-L1 cells were obtained, in accordance to the literature data, using DMI medium supplemented with $1 \mu \mathrm{M}$ rosiglitazone (Fig. 1a and c). [17]. Interestingly, the evaluation of TG content and Oil Red O cell staining indicated that DKE-supplemented DMI medium, without any effect on cell viability, increased the differentiation efficiency by about 2.57 folds compared to that of the control cells cultured in DMI medium without DKE supplementation (Fig. 1a and c).
To evaluate the lipogenic effect of DKE, 3T3-L1 differentiated adipocytes (8 days after the onset of differentiation) were treated for $48 \mathrm{~h}$ with $4 \mu \mathrm{l} / \mathrm{ml}$ DKE and/ or $1 \mu \mathrm{M}$ rosiglitazone. As presented in Fig. $1 \mathrm{~b}$ and d, the triglycerides content of DKE-treated cells increased by almost 54\% $(P<0.05, n=3)$ relative to that of untreated control cells.

\section{PPARY expression in DKE-treated 3T3-L1 cells}

As presented in Fig. 2a, the expression of PPAR $\gamma$, the master regulator of adipogenesis and lipogenesis, increased by about 1.9 folds in 3T3-L1 cells exposed to DKE-supplemented DMI medium relative to cells

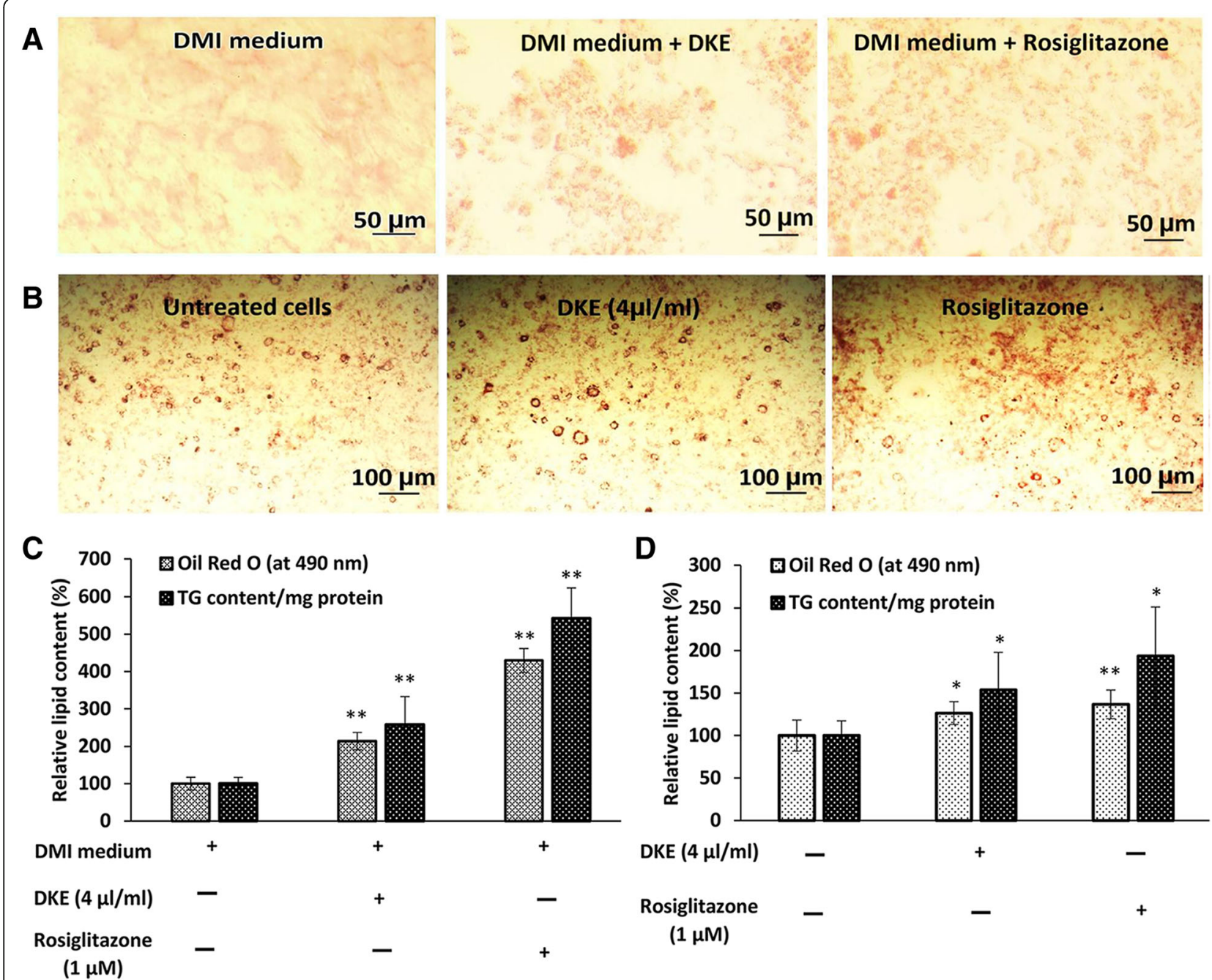

Fig. 1 Evaluation of the adipogenic and lipogenic activities of Dracocephalum kotschyi extract (DKE) in 3T3-L1 cells. a and c cells were cultured for $48 \mathrm{~h}$ in DMI medium (high glucose DMEM containing $1 \mu \mathrm{M}$ dexamethasone, $0.5 \mathrm{mM}$ 3-isobutyl-1-methylxanthine, and $1.5 \mu \mathrm{g} / \mathrm{ml}$ insulin) in the presence or absence of DKE. Then, the DMI medium was replaced with high glucose DMEM containing $10 \mu \mathrm{g} / \mathrm{ml}$ insulin and the differentiation efficiency was evaluated after 6 more days by Oil Red O staining and triglycerides content was determined using the relevant kit. $\mathbf{b}$ and $\mathbf{d}$ to investigate DKE's lipogenic effect, 3T3-L1 cells were differentiated to adipocytes. Eight days after differentiation, cells were treated with $4 \mu \mathrm{l} / \mathrm{ml}$ DKE and/or $1 \mu \mathrm{M}$ rosiglitazone for $48 \mathrm{~h}$ and compared with untreated cells. The data represent a prototype outcome of the control, DKE- and rosiglitazone-treated cells $(n=3)$ 


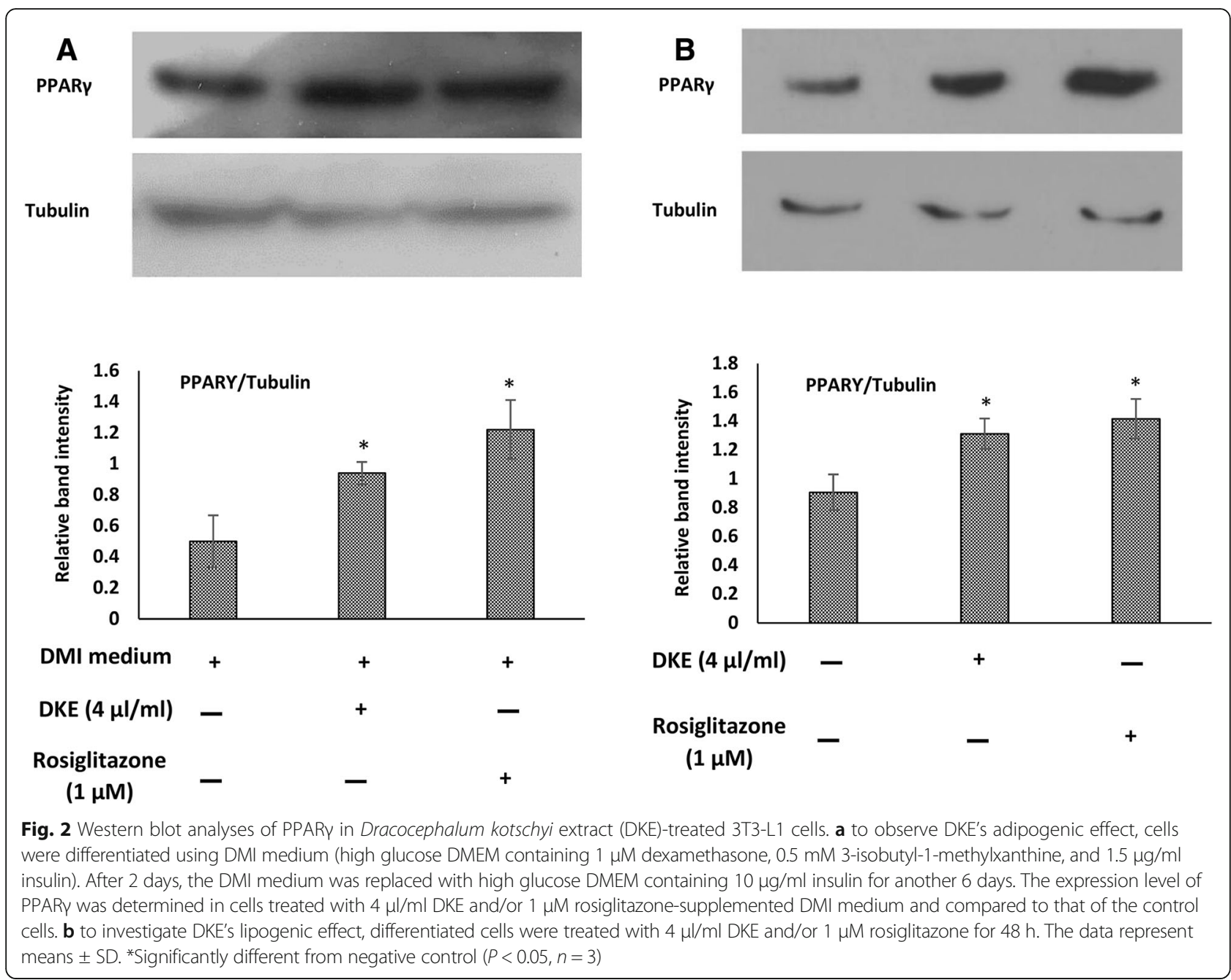

exposed to DMI medium. Furthermore, following differentiation, the expression level of PPAR $\gamma$ was also increased by about $45 \%$ among DKE-treated adipocytes compared to that of untreated cells (Fig. 2b).

\section{In vivo investigations}

As presented in Additional file 1, daily body weight measurement of the diabetic control group showed a body weight loss of around $25 \%$ after 5 weeks while that of DKE-treated group $(0.5 \mathrm{ml} / \mathrm{rat})$ was about $3 \%$. Four weeks of treatment with DKE $(0.5 \mathrm{ml} / \mathrm{rat})$ decreased the level of water intake by $36 \%$ compared to untreated diabetic rats $(P<0.001, n=6)$. Food intake evaluation of different experimental groups demonstrated an almost similar pattern to that of the water intake.

\section{Antidiabetic effects of DKE on STZ-induced diabetic rats} DKE-treatment of diabetic rats for 28 days $(0.25 \mathrm{ml} / \mathrm{rat})$ decreased the level of fasting blood glucose by $22 \%$ and the higher dose of DKE $(0.5 \mathrm{ml} / \mathrm{rat})$ resulted in a $25 \%$ decrease in fasting blood glucose level (Table 1).
Moreover, 28 days of treatment with DKE $(0.25 \mathrm{ml} / \mathrm{rat})$ decreased the sera levels of TG, TC and LDL by 48, 31 and $43 \%$, respectively, compared to the untreated diabetic group, whereas the dose of $0.5 \mathrm{ml} / \mathrm{rat}$ resulted in a decrease of 54, 40 and $54 \%$ in TG, TC and LDL content, respectively. The serum level of HDL was $45 \%$ higher in DKE-treated group $(0.5 \mathrm{ml} / \mathrm{rat})$ than that of the untreated diabetic group (Table 1).

\section{Antioxidant effects of DKE on adipose tissue}

As demonstrated in Table 2, the adipose tissues of DKE-treated rats showed higher $(P<0.05, n=6)$ catalase activities $(54 \%$ and $74 \%$ at doses of 0.25 and $0.5 \mathrm{ml} / \mathrm{rat}$, respectively) compared to the untreated diabetic group. Similarly, SOD activity was increased by $\% 56(P<0.05$, $n=6)$ in adipose tissue of DKE-treated rats $(0.5 \mathrm{ml} / \mathrm{rat})$. Measurement of MDA level in adipose tissue showed the potent ability of DKE to decrease $(P<0.05, n=6)$ the oxidative damage $(0.25 \mathrm{ml} / \mathrm{rat}, 43 \%$ and $0.5 \mathrm{ml} / \mathrm{rat}, 34 \%)$ compared to the untreated diabetic rats. 
Table 1 Antidiabetic effects of DKE

\begin{tabular}{|c|c|c|c|c|c|c|}
\hline Groups & days & Glucose (mg/dl) & $\mathrm{TG}(\mathrm{mg} / \mathrm{dl})$ & $\mathrm{TC}(\mathrm{mg} / \mathrm{dl})$ & $\mathrm{LDL}(\mathrm{mg} / \mathrm{dl})$ & $\mathrm{HDL}(\mathrm{mg} / \mathrm{dl})$ \\
\hline \multirow[t]{3}{*}{ Normal control } & 0 & $131.25 \pm 3.85^{*}$ & $61.73 \pm 2.05^{*}$ & $66.45 \pm 5.85^{*}$ & $18.01 \pm 1.23^{*}$ & $34.02 \pm 0.86^{*}$ \\
\hline & 14 & $132.00 \pm 2.20^{*}$ & $63.98 \pm 3.52^{*}$ & $66.81 \pm 3.44^{*}$ & $19.55 \pm 1.78^{*}$ & $32.68 \pm 1.44^{*}$ \\
\hline & 28 & $127.00 \pm 5.30^{*}$ & $62.33 \pm 3.87^{*}$ & $67.88 \pm 5.31^{*}$ & $20.41 \pm 1.26^{*}$ & $35.04 \pm 1.46^{*}$ \\
\hline \multirow[t]{3}{*}{ Diabetic control } & 0 & $290.80 \pm 18.20$ & $120.44 \pm 4.58$ & $107.76 \pm 5.67$ & $56.72 \pm 4.05$ & $23.38 \pm 0.77$ \\
\hline & 14 & $342.36 \pm 3.96$ & $127.36 \pm 4.69$ & $116.54 \pm 6.04$ & $65.22 \pm 4.11$ & $22.46 \pm 1.61$ \\
\hline & 28 & $393.87 \pm 7.97$ & $143.36 \pm 8.07$ & $117.09 \pm 1.46$ & $76.90 \pm 4.24$ & $21.18 \pm 1.82$ \\
\hline \multirow[t]{3}{*}{ DKE (0.25 ml/rat) } & 0 & $412.58 \pm 17.82$ & $110.35 \pm 8.69$ & $101.72 \pm 6.22$ & $66.11 \pm 3.56$ & $20.16 \pm 1.30$ \\
\hline & 14 & $384.43 \pm 11.07$ & $93.33 \pm 4.99^{*}$ & $99.53 \pm 5.85$ & $52.80 \pm 1.56$ & $23.57 \pm 0.57$ \\
\hline & 28 & $321.07 \pm 4.00^{*}$ & $74.15 \pm 3.33^{*}$ & $80.74 \pm 2.19^{*}$ & $43.75 \pm 2.50^{*}$ & $24.34 \pm 1.72$ \\
\hline \multirow[t]{3}{*}{ DKE (0.5 ml/rat) } & 0 & $379.43 \pm 8.08$ & $117.16 \pm 8.22$ & $106.77 \pm 3.59$ & $57.39 \pm 1.85$ & $22.16 \pm 0.69$ \\
\hline & 14 & $365.22 \pm 3.825$ & $77.62 \pm 3.08^{*}$ & $97.88 \pm 2.37$ & $44.17 \pm 2.06^{*}$ & $26.64 \pm 0.77$ \\
\hline & 28 & $284.80 \pm 6.40^{*}$ & $66.33 \pm 1.76^{*}$ & $69.89 \pm 4.17^{*}$ & $35.26 \pm 3.99^{*}$ & $30.74 \pm 1.15^{*}$ \\
\hline \multirow[t]{3}{*}{ Pioglitazone } & 0 & $342.73 \pm 21.44$ & $99.78 \pm 4.70$ & $116.91 \pm 2.44$ & $61.99 \pm 3.57$ & $23.23 \pm 0.69$ \\
\hline & 14 & $255.89 \pm 7.73^{*}$ & $72.66 \pm 3.40^{*}$ & $92.14 \pm 1.97^{*}$ & $41.26 \pm 1.00^{*}$ & $29.13 \pm 0.92$ \\
\hline & 28 & $178.67 \pm 10.01^{*}$ & $63.63 \pm 2.82^{*}$ & $72.38 \pm 4.46^{*}$ & $24.51 \pm 2.04^{*}$ & $33.25 \pm 1.05^{*}$ \\
\hline
\end{tabular}

Each value represents the mean \pm SD $(n=6)$. ${ }^{*} P<0.05$ statistically different compared to the diabetic control by Student's $t$-test

\section{Increased adipocyte size in DKE-treated rats}

To evaluate the DKE's lipogenic effect, we determined the adipocyte number and respective area in rats' epididymal white adipose tissue. The relevant data (Fig. 3b) demonstrated that the number of adipocytes (per $0.1 \mathrm{~mm}^{2}$ ) in adipose sections was decreased in DKE-treated rats $(0.5 \mathrm{ml} / \mathrm{rat})$ by about $38 \%$ compared to diabetic control group. In addition, DKE-treatment increased the adipocyte area by about 1.9 and 2.2 folds at 0.25 and $0.5 \mathrm{ml} /$ rat (Fig. 3c), respectively.

\section{Decreased level of $p$-JNK in adipose tissue of DKE-treated rats}

The level of p-JNK, as evident from Fig. 4a and c, was increased by almost $68 \%$ in diabetic rats compared to the normal control group. However, DKE at both doses $(0.25$ and $0.5 \mathrm{ml} / \mathrm{rat})$ decreased the phosphorylation level of JNK by about 31 and $40 \%$, respectively, compared to the diabetic control group. The total JNK level remained unchanged in all experimental groups.
Induction of the adipose tissue AKT level in STZ-induced

\section{diabetic rat}

In adipocytes, the well worked out insulin-signaling pathway induces the activation of AKT that becomes evident by increased level of p-AKT [18]. As a consequence of STZ-toxicity in pancreatic beta cells and depletion of secreted insulin, the level of p-AKT decreased in adipose tissue of the diabetic control group by about 2.2 folds compared to normal rats (Fig. $4 a$ and d). Our data indicated that DKE increased the p-AKT level by 52 and $97 \%$ at DKE doses of 0.25 and $0.5 \mathrm{ml} / \mathrm{rat}$, respectively, compared to the control diabetic rats (Fig. $4 \mathrm{a}$ and d).

DKE-mediated modulation of FOXO1 and p-FOXO1 levels Induced kinase activity of AKT is anticipated to increase the phosphorylation level of one of its targets, FOXO1 [19]. Regarding this fact, the level of p-FOXO1 demonstrated a 48 and 51\% increment at DKE doses of 0.25 and $0.5 \mathrm{ml} / \mathrm{rat}$, respectively, compared to the diabetic control group (Fig. 4a and d). Despite these results, the total level of FOXO1

Table 2 DKE's effect on antioxidative enzyme activities and MDA concentration in rats' adipose tissues

\begin{tabular}{llll}
\hline Groups & Catalase $(\mu \mathrm{mol} / \mathrm{min} . \mathrm{mg}$ protein) & $\begin{array}{l}\text { Superoxide dismutase } \\
(\text { U/mg protein) }\end{array}$ & $\begin{array}{l}\text { Malondialdehyde } \\
(\mathrm{nmol} / \mathrm{mg} \text { protein) }\end{array}$ \\
\hline Normal control & $19.52 \pm 0.54^{*}$ & $1.03 \pm 0.06^{*}$ & $6.44 \pm 0.36^{*}$ \\
Diabetic control & $10.24 \pm 0.65$ & $0.48 \pm 0.02$ & $14.73 \pm 0.39$ \\
DKE $(0.25 \mathrm{ml})$ & $15.75 \pm 1.01^{*}$ & $0.52 \pm 0.12$ & $8.44 \pm 0.35^{*}$ \\
DKE $(0.5 \mathrm{ml})$ & $17.79 \pm 0.97^{*}$ & $0.75 \pm 0.05^{*}$ & $9.73 \pm 0.62^{*}$ \\
Pioglitazone & $18.99 \pm 1.46^{*}$ & $0.81 \pm 0.06^{*}$ & $9.07 \pm 0.94^{*}$ \\
\hline
\end{tabular}

The data represent the mean \pm SD $(n=6) .{ }^{*} P<0.05$ significantly different from the diabetic control group 

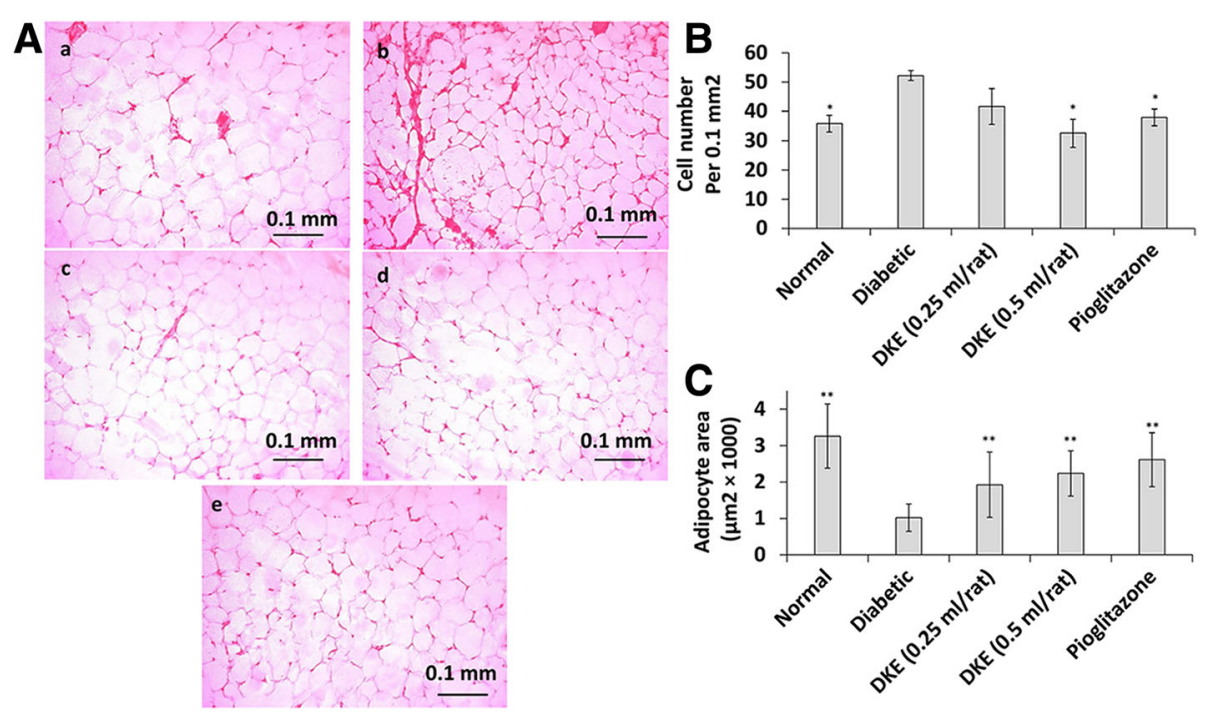

Fig. 3 DKE-treated rats' adipocyte size. a adipose sections were stained with hematoxylin-eosin and adipocytes were counted with light microscope at $\times 200$ magnification. a: Normal rat; b: Diabetic control rat; c: DKE-treated rat $(0.25 \mathrm{ml} / \mathrm{rat})$; d: DKE-treated rat $(0.5 \mathrm{ml} / \mathrm{rat})$; e: Pioglitazone-treated rat. $\mathbf{b}$ the number of adipocytes in $0.1 \mathrm{~mm}^{2}$ of adipose sections. $\mathbf{c}$ adipocyte area of rat groups. The data represent means \pm SD $(n=3) .{ }^{*} P<0.05$ significantly different from diabetic control group. ${ }^{* *} P<0.01$ significantly different from diabetic control group

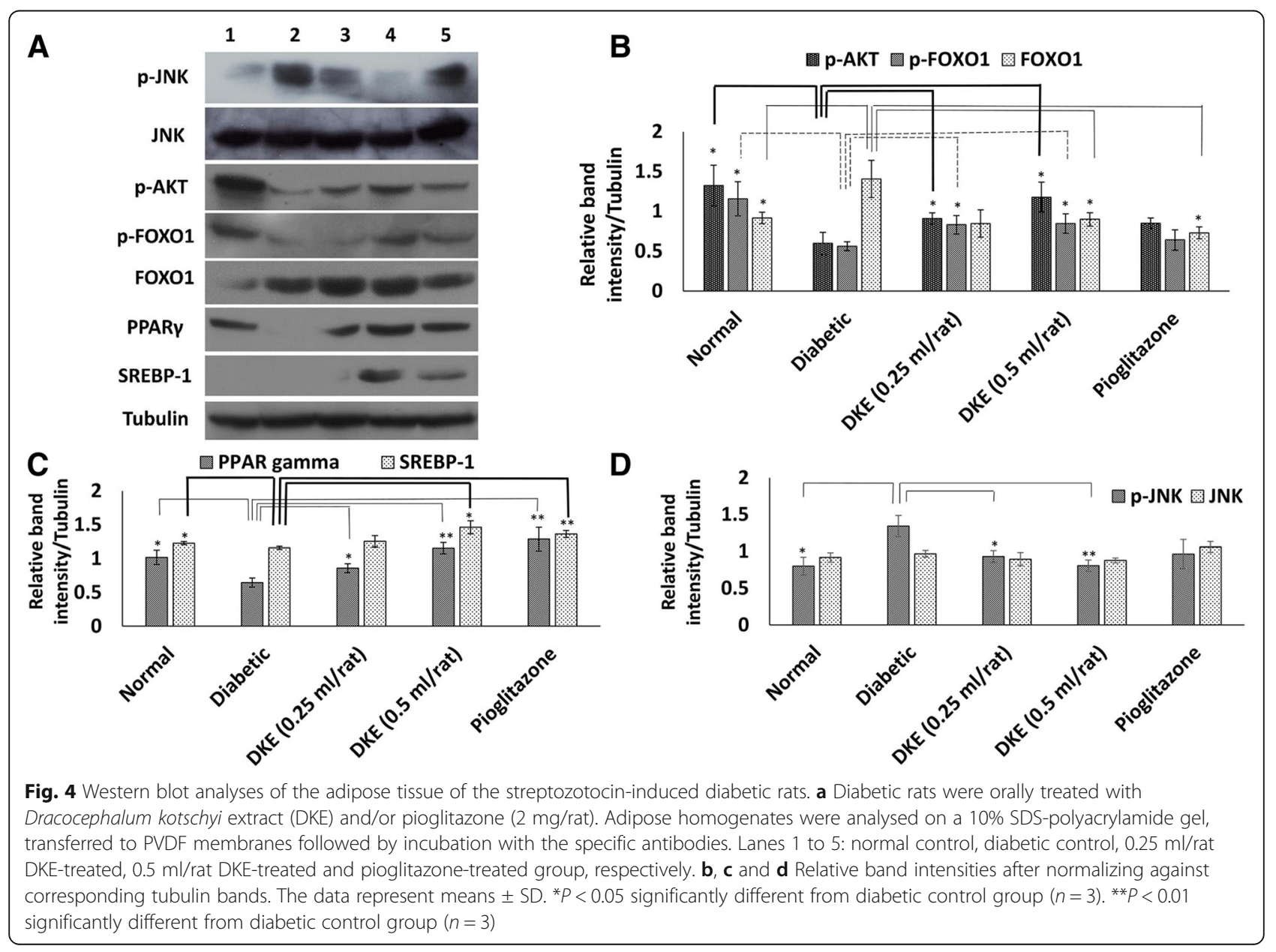


decreased by $36 \%$ at $0.5 \mathrm{ml} / \mathrm{rat}$ dose of DKE relative to the untreated diabetic rats (Fig. $4 \mathrm{a}$ and d).

\section{DKE-treatment induced the expressions of PPAR $y$ and SREBP-1 in adipose tissue}

Our western blot analyses indicated lowered levels of PPAR $\gamma$ expression among the diabetic group compared to the normal rats (Fig. 4a, column no. 2). However, after 28 days of DKE administration to the rats, the adipose tissue expression level of PPARy increased by 33 and $79 \%$ at doses of 0.25 and $0.5 \mathrm{ml} / \mathrm{rat}$, respectively, compared to diabetic control group. Moreover, adipose tissue expression level of SREBP-1 increased by about $26 \%$ in DKE-treated group $(0.5 \mathrm{ml} / \mathrm{rat})$ compared to diabetic control rats (Fig. 4a, columns no. 3 and 4, and Fig. 4b).

\section{Discussion}

Adipose tissue remodeling along with replacement of insulin-resistant adipocytes with younger and more insulin-sensitive cells is one of the therapeutic strategies to revile the diabetic complications. By this aim, thiazolidinediones have been used as PPAR $\gamma$ activators with adipogenic and lipogenic effects on adipose tissue. In this research, pioglitazone, a thiazolidinedione with established antidiabetic and antioxidant properties, was used as the positive control. Indeed our in vivo experiments reconfirmed pioglitazone's antidiabetic and antioxidant effects along with modulated expressions of PPAR $\gamma$, SREBP-1 and total FOXO1 in adipose tissue while, the levels of $\mathrm{p}-\mathrm{AKT}$ and $\mathrm{p}-\mathrm{FOXO1}$ (involved in the insulin-signaling pathway) were not influenced among the positive control rats. Furthermore, our relevant results indicated a strong attenuation of the adipose tissue FOXO1 content among the DKE-treated rats. Consequently, the attenuated level of p-JNK was in line with higher phosphorylation level of AKT leading to down-regulation of FOXO1. Moreover, total FOXO1 expression was attenuated among the DKE-treated rats $(0.5 \mathrm{ml} / \mathrm{rat})$ compared to the diabetic control group. Actually, DKE has been shown to be rich in flavonoids as FOXO1 inhibitors, and previous investigations have demonstrated induced activities of PPARY in several cell lines treated with these bioactive compounds [20,21].

Based on our results, it could certainly be concluded that DKE possesses strong hypolipidemic activity with profound effects on the white adipose tissue. Although the fasting blood glucose level among the extract-treated rats was not restored to the normal level, there was a significant difference in the level of fasting blood glucose among the extract-treated and untreated diabetic rats.

Under insulin-signaling pathway, induction of lipogenesis occurs following activation of AKT and phosphorylation of FOXO1. Our data demonstrated an augmented insulin-signaling pathway in DKE-treated rats with a mechanism that had yet remained to be elucidated. Regarding the STZ-mode of action, it is believed that STZ, as a potent free radical precursor, enters the pancreatic beta cells through the glucose transporter, GLUT2, where it causes DNA alkylation-based cell death with subsequent attenuation of plasma insulin level. These conditions are, furthermore, associated with hyperglycemia, hyperlipidemia and oxidative stress not mentioning other detrimental side effects (for details, please refer to the reviews provided by Eleazu and Szkudelski) [22, 23]. It has been reported that pancreatic beta cells, relatively poor in oxidative stress defense systems, can be protected from diabetic oxidative stress through induction of endogenous antioxidant enzymes or exogenous antioxidant administrations. In fact, our laboratory has previously reported the effect of Teucrium polium extract (from Lamiaceae family) on the regeneration of the $\beta$-cell mass and insulin secretion in STZ-induced diabetic rats [24].

In addition to in vivo experiments, we also evaluated the adipogenic and lipogenic activities of DKE among 3T3-L1 cells which are wildly used as the ideal model system. Due to the differentiation capability of this cell line, it is expected some of the vital transcriptional factors involved in adipogenic and lipogenic processes such as PPAR $y$ and SREBP-1 would undergo modulation. In fact our results confirmed this prediction among 3T3-L1 cells exposed to DKE and/or rosiglitazone, as the positive control. These observations were further supported by the increased adipocytes' area of DKE-treated rats.

In summary, besides of disclosing the hypolipidemic action of DKE, our results provided documents on at least one mode of action of DKE and opened up the field for further evaluation of the plant extract, mainly structure and biological elucidation of DKE main active constituents.

\section{Additional file}

Additional file 1: DKE's effect on mean body weights, food and water intakes in STZ-induced diabetic rats. (PDF $154 \mathrm{~kb}$ )

\section{Abbreviations}

AKT: protein kinase B; DKE: Dracocephalum kotschyi extract;

EDTA: ethylenediaminetetraacetic acid; FOXO1: forkhead box 0-1; JNK: c-Jun $\mathrm{N}$-terminal kinase; MDA: malondialdehyde; NADH: nicotinamide adenine dinucleotide; NBT: nitroblue tetrazolium; PPARy: peroxisome proliferatoractivated receptor gamma; SOD: superoxide dismutase; STZ: streptozotocin; TBA: thiobarbituric acid; TC: total cholesterol; TG: triglycerides

\section{Acknowledgments}

The authors appreciate the financial support of this investigation by the Research Council of University of Tehran. 


\section{Availability of data and materials}

The datasets supporting the conclusions of this article are included within the article and its additional file. More details are available from the corresponding author on reasonable request.

\section{Authors' contributions}

Both authors have made substantial contributions to the followings: the conception and design of the study, data analyses, drafting the article and final approval of the version to be submitted.

\section{Ethics approval and consent to participate}

All procedures performed in studies involving animals were approved by Ethics Committee of University of Tehran.

\section{Consent for publication}

The authors declare that they agree to publish the paper.

\section{Competing interests}

The authors declare that they have no competing interests.

\section{Publisher's Note}

Springer Nature remains neutral with regard to jurisdictional claims in published maps and institutional affiliations.

Received: 15 August 2018 Accepted: 17 October 2018

Published online: 30 October 2018

\section{References}

1. Chao L, Marcus-Samuels B, Mason MM, Moitra J, Vinson C, Arioglu E, Gavrilova O, Reitman ML. Adipose tissue is required for the antidiabetic, but not for the hypolipidemic, effect of thiazolidinediones. J Clin Investig. 2000;106:1221.

2. Tontonoz P, Hu E, Graves RA, Budavari Al, Spiegelman BM. mPPAR gamma 2: tissue-specific regulator of an adipocyte enhancer. Genes Dev. 1994:8:1224-34

3. He W, Barak Y, Hevener A, Olson P, Liao D, Le J, Nelson M, Ong E, Olefsky JM, Evans RM. Adipose-specific peroxisome proliferator-activated receptor $\gamma$ knockout causes insulin resistance in fat and liver but not in muscle. Proc Natl Acad Sci. 2003;100:15712-7.

4. de Souza CJ, Eckhardt M, Gagen K, Dong M, Chen W, Laurent D, Burkey BF. Effects of pioglitazone on adipose tissue remodeling within the setting of obesity and insulin resistance. Diabetes. 2001;50:1863-71.

5. Kim JJ, Li P, Huntley J, Chang JP, Arden KC, Olefsky JM. FoxO1 haploinsufficiency protects against high-fat diet-induced insulin resistance with enhanced peroxisome proliferator-activated receptor $\gamma$ activation in adipose tissue. Diabetes. 2009;58:1275-82.

6. Armoni M, Harel C, Karni S, Chen H, Bar-Yoseph F, Ver MR, Quon MJ, Karnieli E. FOXO1 represses peroxisome proliferator-activated receptor- $\gamma 1$ and- $\gamma 2$ gene promoters in primary adipocytes A NOVEL PARADIGM TO INCREASE INSULIN SENSITIVITY. J Biol Chem. 2006;281:19881-91.

7. Essers MA, Weijzen S, de Vries-Smits AM, Saarloos I, de Ruiter ND, Bos JL, Burgering BM. FOXO transcription factor activation by oxidative stress mediated by the small GTPase Ral and JNK. EMBO J. 2004;23:4802-12.

8. Sajjadi SE, Atar AM, Yektaian A. Antihyperlipidemic effect of hydroalcoholic extract, and polyphenolic fraction from Dracocephalum kotschyi Boiss. Pharm Acta Helv. 1998;73:167-70

9. Li KK, Liu CL, Shiu HT, Wong HL, Siu WS, Zhang C, Han XQ, Ye CX, Leung PC, Ko CH. Cocoa tea (Camellia ptilophylla) water extract inhibits adipocyte differentiation in mouse 3T3-L1 preadipocytes. Sci Rep. 2016;6:20172.

10. Jones BH, Standridge MK, Moustaid N. Angiotensin II increases lipogenesis in 3T3-L1 and human adipose cells. Endocrinology. 1997:138:1512-9.

11. Lowry OH, Rosebrough NJ, Farr AL, Randall RJ. Protein measurement with the Folin phenol reagent. J Biol Chem. 1951;193:265-75.

12. Green $\mathrm{H}$, Kehinde O. Sublines of mouse $3 T 3$ cells that accumulate lipid. Cell. 1974;1:113-6.

13. Galinier A, Carrière A, Fernandez Y, Carpéné C, André M, Caspar-Bauguil S, Thouvenot J-P, Périquet B, Pénicaud L, Casteilla L. Adipose tissue proadipogenic redox changes in obesity. J Biol Chem. 2006;281:12682-7.

14. Robak J, Gryglewski RJ. Flavonoids are scavengers of superoxide anions. Biochem Pharmacol. 1988:37:837-41.

15. Aebi H. [13] Catalase in vitro. Methods Enzymol. 1984;105:121-6.
16. Draper H, Hadley M. [43] malondialdehyde determination as index of lipid peroxidation. Methods Enzymol. 1990;186:421-31.

17. Zebisch K, Voigt V, Wabitsch M, Brandsch M. Protocol for effective differentiation of 3T3-L1 cells to adipocytes. Anal Biochem. 2012:425:88-90.

18. Cho H, Mu J, Kim JK, Thorvaldsen JL, Chu Q, Crenshaw EB, Kaestner KH, Bartolomei MS, Shulman Gl, Birnbaum MJ. Insulin resistance and a diabetes mellitus-like syndrome in mice lacking the protein kinase Akt2 (PKBß). Science. 2001;292:1728-31.

19. Kitamura T, Nakae J, Kitamura Y, Kido Y, Biggs WH, Wright CV, White MF, Arden KC, Accili D. The forkhead transcription factor Foxo1 links insulin signaling to $\mathrm{Pdx} 1$ regulation of pancreatic $\beta$ cell growth. J Clin Invest. 2002;110:1839-47.

20. Shi T, Zhuang R, Zhou H, Wang F, Shao Y, Cai Z. Effect of apigenin on protein expressions of PPARs in liver tissues of rats with nonalcoholic steatohepatitis. Zhonghua Gan Zang Bing Za Zhi. 2015;23:124-9.

21. Ding $L$, Jin $D$, Chen $X$. Luteolin enhances insulin sensitivity via activation of PPARy transcriptional activity in adipocytes. J Nutr Biochem. 2010;21:941-7.

22. Eleazu CO, Eleazu KC, Chukwuma S, Essien UN. Review of the mechanism of cell death resulting from streptozotocin challenge in experimental animals, its practical use and potential risk to humans. J Diabetes Metab Disord. 2013;12:60

23. Szkudelski T. The mechanism of alloxan and streptozotocin action in B cells of the rat pancreas. Physiol Res. 2001;50:537-46.

24. Tabatabaie PS, Yazdanparast R. Teucrium polium extract reverses symptoms of streptozotocin-induced diabetes in rats via rebalancing the $\mathrm{Pdx} 1$ and Fox01 expressions. Biomed Pharmacother. 2017:93:1033-9.
Ready to submit your research? Choose BMC and benefit from:

- fast, convenient online submission

- thorough peer review by experienced researchers in your field

- rapid publication on acceptance

- support for research data, including large and complex data types

- gold Open Access which fosters wider collaboration and increased citations

- maximum visibility for your research: over 100M website views per year

At BMC, research is always in progress.

Learn more biomedcentral.com/submissions 